\title{
Repackaging as a Strategy to Increase Efficiency in Extension Programs ${ }^{1}$
}

\author{
Laura A. Sanagorski
}

\section{Introduction}

Extension has drastically changed over the past few decades, with the number of agents and amount of resources reduced nationwide. The new reality means individual Extension agents' responsibilities have increased, leaving them to do more with less (Clary, White, \& Mullins, 2000). As Clary et al. describe it, "(b)eing in touch with a larger number of people in more divergent locations is the reality of Extension agents' duties" (2000, para. 5). Despite new challenges, Extension professionals still work to ensure that their creative and educational materials reach as many outlets and clients as they possibly can. A strategy for facing this challenge is to repackage materials in different formats for different audiences. (Repackaging is a way to reuse the research and writing one has done on a particular topic by formatting it in multiple formats for several audiences.) The purpose of this article is to encourage repackaging as a strategy to increase efficiency in Extension programming and to make recommendations for specific applications of this methodology.

\section{Repackaging Extension Outputs}

Extension professionals must frequently choose what activities they pursue and what needs they address. The use of multiple creative outputs allows agents to reach more people in different audiences and achieve a greater return on time invested. Extension professionals spend a substantial amount of time researching specific topics in their fields and translating research-based information into a number of creative outlets. This research may be translated for clients through consulting emails, telephone calls, site visits, lectures, PowerPoint presentations, websites, newsletter articles, and many other outlets. The following is a list of some of the many outlets that may be considered.

- Blog post

- County fact sheet

- Email written report (to client)

- Electronic data information source (EDIS) document

- Newsletter article (print-based)

- Written report (to employer: county / Extension system)

- Written scenario for training presentation

- Journal article

- E-newsletter article

- Press release

- Social media post (Facebook, Twitter)

- Online photo database

- Online video

- Public service announcement

- Section in a diagnostic manual / toolkit

Repackaging is a great strategy for any agent with a heavy workload and multiple or segmented audiences.

1. This document is AEC492 (formerly WC155), one of a series of the Agricultural Education and Communication Department, UF/IFAS Extension. Original publication date October 2013. Visit the EDIS website at http://edis.ifas.ufl.edu.

2. Laura A. Sanagorski, assistant professor, Department of Agricultural Education and Communication, UF/IFAS Extension, Gainesville, FL 32611.

The Institute of Food and Agricultural Sciences (IFAS) is an Equal Opportunity Institution authorized to provide research, educational information and other services only to individuals and institutions that function with non-discrimination with respect to race, creed, color, religion, age, disability, sex, sexual orientation, marital status, national origin, political opinions or affiliations. For more information on obtaining other UF/IFAS Extension publications, contact your county's UF/IFAS Extension office. 
The following scenario illustrates this strategy applied to the workload of an Extension professional working in horticulture.

Example: An environmental horticulture agent conducts a site visit to assist a professional client in diagnosing a landscape disorder. The agent identifies the problem as a specific pest infestation and spends a few hours researching the available courses of treatment for the client. The agent spends additional time writing an email report presenting possible solutions to the problem and providing additional recommendations for keeping the landscape healthy and reducing the chance of pest problems in the future. While the recipient of the report will greatly appreciate the diagnosis and follow-up report, the time spent researching and writing could be leveraged into numerous other outlets that serve many additional clients.

With a little more effort, this diagnosis and report could be repackaged in many ways. For example, the agent could rewrite the report for a general audience and post it on on the county website. Photos of the problem with a brief identification and solution could be used as part of a disorder-identification tool, either online or in print, or both. The report could be reworked into newsletter and newspaper articles for professional and homeowner audiences. It could also be reworked into a county fact sheet for clients with the same pest problem. The situation (photos of symptoms and signs) could be presented as part of an identification activity during a workshop for professionals or master gardeners.

While printed educational materials are still highly relevant in education, Extension is no longer dependent on print-only forms of communication and now relies more heavily on electronic communication (Franzen-Castle, Henneman, \& Ostdiek, 2013). Technology-based channels should be considered as a means for increased efficiency as well as ways to reach new audiences (Diem, Hino, Martin, \& Meisenbach, 2011). The use of both electronic and print communications, and even multiple digital channels for reaching clients, can expand an agent's reach exponentially. Figure 1 illustrates the potential outlets and reach of a single email, repackaged. This email to a single client is rewritten to serve the needs of many audiences. The topic could include any subject an agent teaches, ranging from advice on how to manage a residential lawn during times of drought stress, to identifying a specific pest problem, to making recommendations about the best course of establishing credibility as a green industry professional.

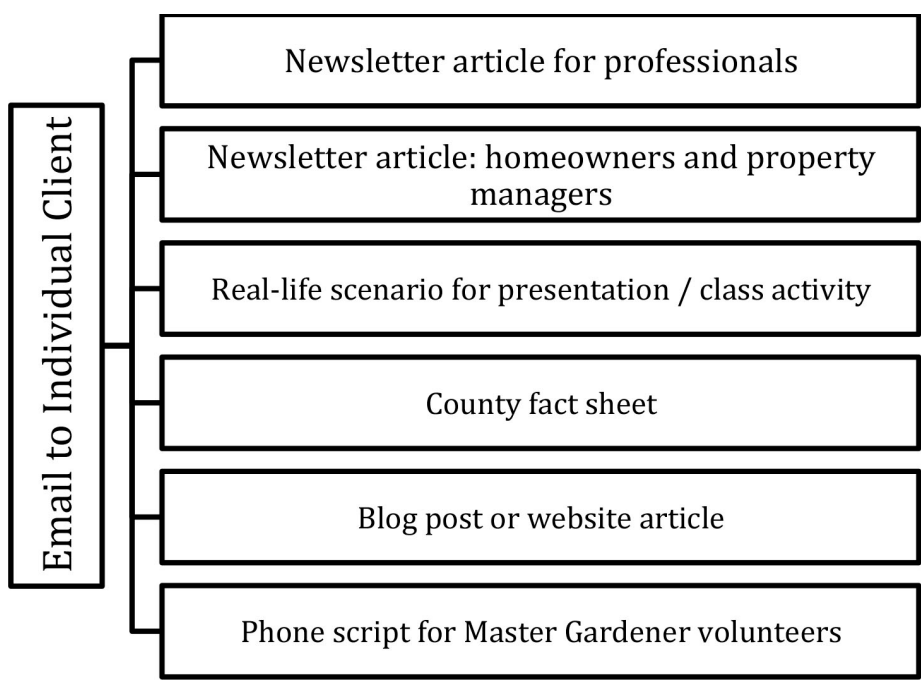

Figure 1. A representation of the potential reach of the research invested in one email when repackaged for various audiences.

\section{Best Management Practices for Repackaging Extension Materials}

The following is a summary of recommended best management practices for using this strategy.

- When creating any educational output, Extension professionals should consider the following:

- Would this material be useful to additional Extension clients?

- Where are those clients and how can they be reached?

- Schedule regular times to review existing pieces and then rewrite and repackage the materials. Explore both public materials (such as class handouts) and private materials (such as email correspondence).

- Consider writing a comprehensive primary piece once, and then adapting it into other formats. (Example: an extensive report may be broken into smaller pieces.

- Adapt materials to meet the needs of the intended user. Content should reflect what the specific audience wants to know using terminology that they understand and the language they speak.

- Consider adapting materials in both printed and electronic formats.

- When adapting a written piece to a digital one, ensure that the piece is concise and visually appealing.

- Consider reusing photos and samples submitted by clients. (Example: when a client submits a physical sample for species identification, take a photo of the sample, and use it to educate other audiences.) 
- When creating electronic materials, such as blog posts or web pages, create a printer-friendly (PDF) version that can be easily accessed and shared with clients.

- Develop an organizational system that allows clients to find materials easily, with minimal or no assistance. This could be in the form of an online list linking to fact sheets or an in-office directory of county fact sheets.

- Build an evaluation component in to repackaged activities. At a minimum, this would include the numbers of clients using materials, which could consist of website views, paper copies distributed, or materials requested from an Extension office. The evaluation component would be strengthened if a mechanism for contacting and surveying users was created to determine outcomes of using the materials. (Example: a mailed follow-up survey to a sample of clients who have requested written materials.)

- Consider forming a network with other professionals who have similar responsibilities and then partner in sharing and repackaging materials. (Example: a tricounty horticulture agent partnership.)

\section{Conclusion}

This article presented a basic overview of repackaging materials in order to reach more people in multiple audiences. Extension professionals should consider how their work could be reinterpreted and reused to meet needs in the diverse communities they serve. This strategy allows Extension to ultimately do more with less and reach more of its audience through various channels. In the words of Franzen-Castle et al. (2013, para. 7), "(o)ur audiences are already everywhere, so we need to be there too".

\section{References}

Clary, J., White, B., \& Mullins, G. (2000). The influence of cellular telephone usage on the perceived role and functions of county agents. Journal of Extension [On-line], 38(3) Article 3RIB1. Retrieved from: http://www.joe.org/ joe/2000june/rb1.php

Diem, K., Hino, J, Martin, D., \& Meisenbach, T. (2011). Is Extension ready to adopt technology for delivering programs and reaching new audiences? Journal of Extension [On-line], 49(6) Article 6FEA1. Available at: http://www. joe.org/joe/2011december/a1.php
Franzen-Castle, L., Henneman, A., \& Ostdiek, D. (2013). "Reduce" your work load, "re-use" existing extension print materials, and "recycle" to new digital platforms. Journal of Extension [On-line], 51(4) Article 4TOT2. Retrieved from: http://www.joe.org/joe/2013august/pdf/JOE_v51_4tt2.pdf 